\title{
Numerical Simulations of Boiling Jet Impingement Cooling in Power Electronics
}

Conference Paper NREL/CP-540-39401

December 2006

S. Narumanchi, V. Hassani, and D. Bharathan National Renewable Energy Laboratory

A. Troshko

Fluent, Inc.

Presented at ITHerm 2006 (Intersociety Conference on Thermal and Thermomechanical Phenomena in Electronic Systems)

San Diego, California

May 30-June 2, 2006 


\section{NOTICE}

The submitted manuscript has been offered by an employee of the Midwest Research Institute (MRI), a contractor of the US Government under Contract No. DE-AC36-99G010337. Accordingly, the US Government and MRI retain a nonexclusive royalty-free license to publish or reproduce the published form of this contribution, or allow others to do so, for US Government purposes.

This report was prepared as an account of work sponsored by an agency of the United States government. Neither the United States government nor any agency thereof, nor any of their employees, makes any warranty, express or implied, or assumes any legal liability or responsibility for the accuracy, completeness, or usefulness of any information, apparatus, product, or process disclosed, or represents that its use would not infringe privately owned rights. Reference herein to any specific commercial product, process, or service by trade name, trademark, manufacturer, or otherwise does not necessarily constitute or imply its endorsement, recommendation, or favoring by the United States government or any agency thereof. The views and opinions of authors expressed herein do not necessarily state or reflect those of the United States government or any agency thereof.

Available electronically at http://www.osti.gov/bridge

Available for a processing fee to U.S. Department of Energy and its contractors, in paper, from:

U.S. Department of Energy

Office of Scientific and Technical Information

P.O. Box 62

Oak Ridge, TN 37831-0062

phone: 865.576 .8401

fax: 865.576 .5728

email: mailto:reports@adonis.osti.gov

Available for sale to the public, in paper, from:

U.S. Department of Commerce

National Technical Information Service

5285 Port Royal Road

Springfield, VA 22161

phone: 800.553 .6847

fax: 703.605.6900

email: orders@ntis.fedworld.gov

online ordering: http://www.ntis.gov/ordering.htm 


\title{
NUMERICAL SIMULATIONS OF BOILING JET IMPINGEMENT COOLING IN POWER ELECTRONICS
}

\author{
Sreekant Narumanchi ${ }^{1}$, Andrey Troshko, ${ }^{2}$ Vahab Hassani, ${ }^{1}$ and Desikan Bharathan ${ }^{1}$ \\ 1. National Renewable Energy Laboratory, \\ 1617 Cole Blvd, \\ Golden, CO, USA 80401 \\ *Phone: (303)275-4062 \\ Fax: (303)275-4415 \\ *Email: sreekant_narumanchi@nrel.gov \\ 2. Fluent Inc., \\ 10 Cavendish Court, Centerra Park Resource, \\ Lebanon, NH, USA 03766
}

\begin{abstract}
Boiling jet impingement cooling is currently being explored to cool power electronics components. In hybrid vehicles, inverters are used for DC-AC conversion. These inverters involve a number of insulated gate bipolar transistors (IGBTs), which are used as on/off switches. The heat dissipated in these transistors can result in heat fluxes of up to $200 \mathrm{~W} / \mathrm{cm}^{2}$, which makes the thermal management problem quite important.

In this paper, turbulent jet impingement involving nucleate boiling is explored numerically. The framework for these computations is the CFD code FLUENT. For nucleate boiling, the Eulerian multiphase model is used. A mechanistic model of nucleate boiling is implemented in a user-defined function (UDF) in FLUENT. The numerical results for boiling water jets (submerged) are validated against existing experimental data in the literature. Some representative IGBT package simulations that use R134a as the cooling fluid are also presented.
\end{abstract}

KEY WORDS: boiling, power electronics, numerical simulations, CFD, IGBTs

\section{NOMENCLATURE}

$C_{\varepsilon 1}, C_{\varepsilon 2}$ Constants

$\mathrm{C}_{\mathrm{P}} \quad$ Specific heat, $\mathrm{J} / \mathrm{KgK}$

d Jet diameter, $\mathrm{m}$

D Target equivalent diameter, $\mathrm{m}$

f Bubble departure frequency, $\mathrm{Hz}$

$\vec{F} \quad$ Force vector, $\mathrm{N} / \mathrm{m}$

$\vec{g} \quad$ Gravitational acceleration vector, $\mathrm{m} / \mathrm{s}^{2}$

$\mathrm{G} \quad$ Term in the turbulent kinetic energy equation, $\mathrm{kg} / \mathrm{ms}^{3}$

h Heat transfer coefficient, $\mathrm{W} / \mathrm{m}^{2} \mathrm{~K}$

IGBT Insulated-gate bipolar transistor

k Thermal conductivity, $\mathrm{W} / \mathrm{mK}$

$\mathrm{k}$ Turbulence kinetic energy, $\mathrm{m}^{2} / \mathrm{s}^{2}$

L Latent heat, $\mathrm{J} / \mathrm{kg}$

$\dot{m} \quad$ Mass transfer, $\mathrm{kg} / \mathrm{m}^{3} \mathrm{~s}$

$\begin{array}{ll}\mathrm{n} & \text { Nucleation site density } \\ \mathrm{p} & \text { Pressure, } \mathrm{N} / \mathrm{m}^{2} \\ \mathrm{Pr} & \text { Prandtl number } \\ q, q^{\prime \prime} & \text { Heat flux, } \mathrm{W} / \mathrm{m}^{2} \\ \vec{q} & \text { Heat flux vector, } \mathrm{W} / \mathrm{m}^{2} \\ \mathrm{Q} & \text { Interfacial energy exchange, } \mathrm{W} / \mathrm{m}^{3} \\ \vec{R} & \text { Interfacial drag force, } \mathrm{N} / \mathrm{m}^{3} \\ \mathrm{Re} & \text { Reynolds number } \\ \mathrm{S} & \text { Source term in energy equation, } \mathrm{W} / \mathrm{m}^{3} \\ S_{k} & \text { Source term in turbulent kinetic energy equation, } \\ & \text { kg/ms } \\ S_{\varepsilon} & \text { Source term in dissipation rate equation, } \mathrm{kg} / \mathrm{ms}^{4} \\ \mathrm{u}, \mathrm{U} & \text { Liquid velocity, } \mathrm{m} / \mathrm{s} \\ \mathrm{v} & \text { Phase velocity, } \mathrm{m} / \mathrm{s} \\ \vec{v} & \text { Jet velocity at the nozzle exit, } \mathrm{m} / \mathrm{s} \\ & \text { Velocity vector, } \mathrm{m} / \mathrm{s}\end{array}$

\section{Greek symbols}

$\alpha \quad$ Phase volume fraction

$\Delta T \quad$ Temperature difference, $\mathrm{K}$

$\varepsilon \quad$ Dissipation rate, $\mathrm{m}^{2} / \mathrm{s}^{3}$

$\kappa \quad$ Thermal conductivity, $\mathrm{W} / \mathrm{mK}$

$\mu \quad$ Dynamic viscosity, $\mathrm{Ns} / \mathrm{m}^{2}$

$v \quad$ Kinematic viscosity, $\mathrm{m}^{2} / \mathrm{s}$

$\rho \quad$ Density, $\mathrm{Kg} / \mathrm{m}^{3}$

$\sigma \quad$ Surface tension, $\mathrm{N} / \mathrm{m}$

$\bar{\tau} \quad$ Shear stress, $\mathrm{N} / \mathrm{m}^{2}$

\section{Subscripts}

avg Average

CHF Corresponding to critical heat flux

$d \quad$ Jet diameter

$f \quad$ Corresponding to fluid

$l \quad$ Corresponding to liquid 
Corresponding to interaction between liquid and vapor

$p q \quad$ Corresponding to interaction between phases $\mathrm{p}$ and $\mathrm{q}$

$q \quad$ Corresponding to phase $\mathrm{q}$

sat Corresponding to saturation

sub Corresponding to subcooling

$v \quad$ Corresponding to vapor

\section{INTRODUCTION}

Single-phase liquid jets have been studied very extensively in the literature [1-4]. These studies include experiments, theoretical analyses, and numerical simulations. Considerable attention has also been focused on boiling jets. Boiling liquid jets take advantage of the latent heat of vaporization of the fluid to provide fairly high heat transfer coefficients $(>20,000$ $\mathrm{W} / \mathrm{m}^{2} \mathrm{~K}$ ), which makes them attractive for electronic cooling applications. The boiling curve for a saturated liquid is shown in Fig. 1.

Typically, for electronic cooling applications, nucleate boiling is the preferred regime of operation because a small increase in wall superheat is accompanied by a large increase in the wall heat flux dissipated. Also, in electronics, it may not be possible to afford very large temperature differences between the solid surfaces and the liquid - a characteristic essential for regimes such as film boiling.

In the context of boiling liquid jets, extensive work has already been reported in the literature [5-9]. Many studies have been carried out with circular [10-17] as well as planar [18-21] jets in both free-surface and submerged configurations. This includes single and multiple jets $[14,22-$ 26].

In the nucleate boiling literature, most of the correlations are cited in the following form:

$$
q_{\text {sat }}{ }^{\prime \prime}=C \Delta T_{\text {sat }}{ }^{m}
$$

where $C$ and $m$ are determined by curve fit to the experimental data, $\Delta T_{\text {sat }}=\mathrm{T}_{\text {wall }}-\mathrm{T}_{\text {sat }}$ is the wall superheat, $\mathrm{T}_{\text {sat }}$ is the saturation temperature of the fluid, $T_{\text {wall }}$ is the wall temperature, and $q_{\text {sat }}^{\prime \prime}$ is the wall flux.

Most of the heat transfer data are cited in the form given in Eq. 1, which can be rewritten as:

$$
h=\frac{q^{\prime \prime}}{\Delta T_{\text {sub }}+\left(\frac{q^{\prime \prime}}{C}\right)^{1 / m}}
$$

where $h$ is the heat transfer coefficient, $\Delta T_{\text {sub }}=\mathrm{T}_{\mathrm{sat}}-\mathrm{T}_{\mathrm{f}}$, where $T_{f}$ is the fluid temperature, is the amount of subcooling in the fluid.

Nucleate boiling is governed by intense bubble motion and mixing, so it is a strong process that does not depend on many jet parameters, unlike single-phase jets. Jet diameter, jet orientation, number of jets, jet configuration (free-surface or submerged), and even jet velocity do not have much effect on the heat transfer in nucleate boiling [5].

The target surface plays a critical role in the bubble nucleation process [27]. In fact, much of the difficulty in obtaining truly non-dimensional correlations for nucleate boiling arises from this. Surface conditions, surface aging, and even the condition of the surface during the course of an experiment [10] all have a considerable impact on the heat transfer results.

The other aspect that has been given considerable attention is the critical heat flux (CHF) (Fig. 1) [5, 8]. When CHF occurs, the temperature of the wall shoots up because of dry-out conditions in which no liquid is in contact with the surface to sustain boiling. A schematic of this phenomenon is shown in Fig. 2 [5]. The liquid sub-layer (Fig. 2) drawn from the main liquid jet supply sustains the boiling process. When liquid cannot be supplied to this sub-layer, dry-out occurs, and CHF is reached.

Considerable work has been done to develop non-dimensional correlations that show the dependence of the CHF on other parameters $[13,25,28-32]$. Typically in the literature, empirical correlations are presented only for certain simple geometries. For thermal design that involves more complicated geometries, it is important to have CFD modeling capability. Although multiphase models have been presented in the literature [33, 34], CFD modeling of boiling jets is still in its infancy $[35,36]$. Numerical studies of phenomena such as nucleate pool boiling [37] and film boiling [38-40] are just beginning to appear in the literature.

A significant amount of experimental work has also been reported in the literature on spray cooling (e.g. [41-43]). Both sprays and jets have their advantages and disadvantages. For some applications, sprays might be more suitable, while for others, jets may be a better choice.

This paper presents CFD modeling of jets involving nucleate boiling. It is not possible to model boiling jets in the commercially available version of FLUENT, so a user-defined function (UDF) was used to perform these simulations. For nucleate boiling, the Eulerian multiphase model is used. A mechanistic model of nucleate boiling is implemented in a UDF in FLUENT. The numerical predictions are validated against experimental studies on submerged jets involving nucleate boiling. These experimental studies involve water and R-113 as the fluids. After this, IGBT package simulations are reported with a submerged boiling jet of water.

To the best of our knowledge, these validations and IGBT package simulations with boiling jets are being reported for the first time. A comparison between single-phase and boiling jets from the heat transfer viewpoint and in the context of cooling the IGBT package is also presented. 


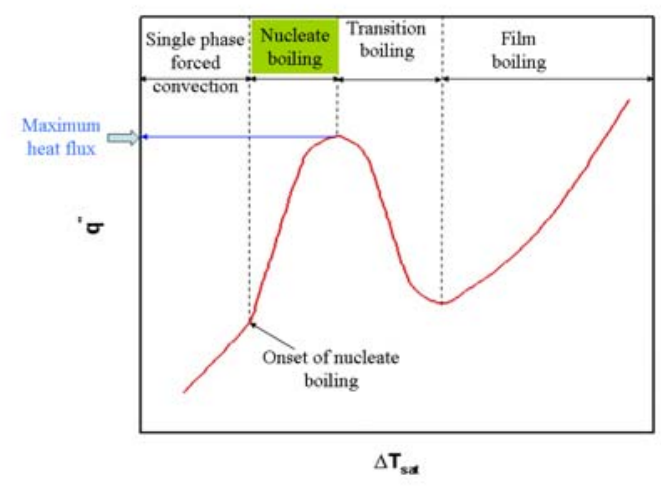

Fig. 1 General boiling curve for saturated liquids

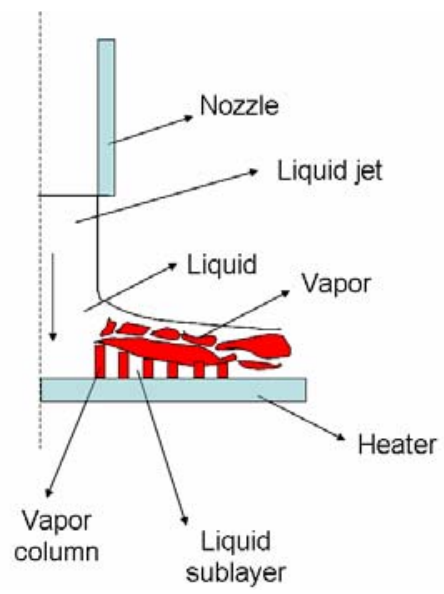

Fig. 2 Mechanism by which critical heat flux occurs

\section{CFD MODELING OF JETS IN THE NUCLEATE BOILING REGIME: VALIDATION WITH EXPERIMENTS}

In this section, we present CFD modeling of jets in the nucleate boiling regime.

Eulerian multiphase model description. The following are equations for the conservation of mass, momentum, and energy for the Euler multiphase model $[33,34]$ implemented in FLUENT 6.2.

Mass conservation equation for phase q:

$\frac{\partial}{\partial t}\left(\alpha_{q} \rho_{q}\right)+\nabla \cdot\left(\alpha_{q} \rho_{q} \vec{v}_{q}\right)=\sum_{p=1}^{n} \dot{m}_{p q}$

where $\alpha$ is the phase fraction of phase $q, \rho$ is the density, $\vec{v}$ is the velocity vector and $\dot{m}$ is the mass exchange between phases $p$ and $q$.

Momentum conservation equation for phase q:

$\frac{\partial}{\partial t}\left(\alpha_{q} \rho_{q} \vec{v}_{q}\right)+\nabla \cdot\left(\alpha_{q} \rho_{q} \vec{v}_{q} \vec{v}_{q}\right)=-\alpha_{q} \nabla p+\nabla \cdot \overline{\bar{\tau}}_{q}+\alpha_{q} \rho_{q} \vec{g}_{q}$

$+\sum_{p=1}^{n}\left(\vec{R}_{p q}+\dot{m}_{p q} \vec{v}_{p q}\right)+\alpha_{q} \rho_{q}\left(\vec{F}_{q}+\vec{F}_{l i f, q}+\vec{F}_{v m, q}\right)$ where $\underset{\tau}{\tau}$ is the shear stress, $\vec{R}$ is the interfacial drag force, $\vec{F}_{q}$ is the turbulent diffusion force, $\vec{F}_{l i f t, q}$ is the lift force, $p$ is the pressure, and $\vec{g}$ is the gravitational acceleration vector.

Energy conservation equation for phase q:

$\frac{\partial}{\partial t}\left(\alpha_{q} \rho_{q} h_{q}\right)+\nabla \cdot\left(\alpha_{q} \rho_{q} \vec{v}_{q} h_{q}\right)=-\alpha_{q} \frac{\partial p}{\partial t}+\overline{\bar{\tau}}_{q}: \nabla \vec{v}_{q}-$

$\nabla \vec{q}_{q}+S_{q}+\sum_{p=1}^{n}\left(Q_{p q}+\dot{m}_{p q} h_{p q}\right)$

where $h$ is the enthalpy, $\vec{q}$ is the heat flux vector, $S$ is the source term, and $Q$ is the energy exchange term between the different phases.

The following are restrictions on interfacial mass, momentum, and energy interfacial exchange terms:

$$
\begin{aligned}
& \dot{m}_{p q}=-\dot{m}_{q p}, \dot{m}_{p p}=0 \\
& \vec{R}_{p q}=-\vec{R}_{q p}, \vec{R}_{p p}=0 \\
& Q_{p q}=-Q_{q p}, Q_{p p}=0
\end{aligned}
$$

Most sub-cooled boiling flows are turbulent, so the mixture phase k-epsilon model is used:

$$
\begin{aligned}
\frac{\partial}{\partial t}\left(\rho_{m} k\right)+\nabla \cdot\left(\rho_{m} \vec{v}_{m} k\right)= & -\nabla \cdot\left(\frac{\mu_{t, m}}{\operatorname{Pr}_{k}} \nabla k\right)+G_{k, m} \\
& -\rho_{m} \varepsilon+S_{k}
\end{aligned}
$$

where $k$ is the turbulent kinetic energy, $\mu$ is the viscosity, $\varepsilon$ is the dissipation rate, $G$ and $S$ are source terms in the turbulent kinetic energy equation.

$$
\begin{aligned}
& \frac{\partial}{\partial t}\left(\rho_{m} \varepsilon\right)+\nabla \cdot\left(\rho_{m} \vec{v}_{m} \varepsilon\right)=-\nabla \cdot\left(\frac{\mu_{t, m}}{\operatorname{Pr}_{\varepsilon}} \nabla \varepsilon\right) \\
& +\frac{\varepsilon}{k}\left(C_{\varepsilon 1} G_{k, m}-C_{\varepsilon 2} \rho_{m} \varepsilon\right)+S_{\varepsilon}
\end{aligned}
$$

where $C_{\varepsilon 1}, C_{\varepsilon 2}$ are constants, and $S_{\varepsilon}$ is a source term in the dissipation rate equation.

What follows is a closure for interfacial terms in the subcooled boiling model.

\section{Mass conservation equation.}

Rate of vapor formation per unit of volume in Eq. 1 becomes:

$\sum_{p=1}^{n} \dot{m}_{q p}=\dot{m}_{l v}=h_{l v}\left(T_{l}-T_{s}\right) A_{i} / L$
$+q_{E}^{\prime \prime} A_{w} /\left(L+C_{p l} \max \left(T_{s}-T_{l}, 0\right)\right)$

where $h_{l v}$ is the interfacial heat transfer coefficient calculated from the Ranz-Marshall correlation;

$A_{i}=6 \alpha_{s v}\left(\left(1-\alpha_{v}\right) /\left(1-\alpha_{s v}\right)\right) / d_{v}$

is the interfacial area density, where $\alpha_{s v}=\min \left(\alpha_{v}, 0.25\right)$

(Kurul and Podowski [33]); $q_{E}^{\prime \prime}$ is the evaporating heat flux calculated from the RPI model $[33,34] ; L=h_{v s}^{0}-h_{l s}^{0}$ is the latent heat per unit of mass; $A_{w}=\delta\left(\vec{x}-\vec{x}_{w}\right)$ is interfacial area density of wall surface; and $d$ is the diameter of the 
secondary phase (vapor bubble). Here, subscripts $l, v$, and $s$ mean liquid phase, vapor phase, and saturation state, respectively. In discretized form, $A_{w}$ becomes the ratio of the cell face area constituting the wall to the cell volume. The rate of condensation $\dot{m}_{v l}$ is calculated from Eq. 11 .

Momentum conservation equation. The interfacial drag

force per unit of volume is calculated as:

$\vec{R}_{l v}=0.75 \cdot C_{d} \cdot \rho_{l} \cdot \alpha_{v} \cdot\left|\vec{v}_{r}\right| \cdot \vec{v}_{r} / d_{v}$

where the drag coefficient $C_{d}$ is calculated as:

$C_{d}=\operatorname{MIN}\left(C_{d}^{\text {dis }}, C_{d}^{v i s}\right)$

where $C_{d}^{\text {dis }}$ and $C_{d}^{\text {vis }}$ are known drag correlations calculated for distorted and viscous regimes accounting for the high concentration effect:

$$
\begin{aligned}
& C_{d}^{v i s}=\frac{24}{\operatorname{Re}_{b}}\left(1+0.1 \operatorname{Re}_{b}^{0.75}\right) \cdot\left(\operatorname{MAX}\left(\alpha_{l}, 0.5\right)\right)^{-2} \\
& C_{d}^{d i s}=\frac{2 d_{v}}{3}\left(g\left(\rho_{l}-\rho_{v}\right) / \sigma\right)^{1 / 2} \cdot\left(\operatorname{MAX}\left(\alpha_{l}, 0.5\right)\right)^{-1}
\end{aligned}
$$

The lift-force coefficient is calculated as (Moraga et al. [44]):

$$
C_{l}=\left(\begin{array}{l}
0.0767, \phi \leq 6000 \\
-\left(0.12-0.2 e^{-\phi / 36000}\right) e^{\phi / 3 e+07} \\
-0.002, \phi \geq 1.9 e+05
\end{array}, 6000<\phi<1.9 e+05\right.
$$

where $\phi=\operatorname{Re}_{b} \operatorname{Re}_{v}$. This lift coefficient combines the opposing actions of two lift forces. "Classical" aerodynamics lift force results from interaction between bubble and liquid shear, and lateral force results from interaction between bubbles and vortices shed by bubble wake. Here, $\operatorname{Re}_{b}=d_{v}\left|\vec{v}_{r}\right| / v_{l}$ is the bubble Re, and $\operatorname{Re}_{v}=d_{v}^{2}\left|\nabla \times \vec{v}_{l}\right| / v_{l}$ is the bubble shear Re.

Turbulent diffusion force is calculated as [33]:

$\vec{F}_{v}=-\vec{F}_{l}=-C_{T D} \rho_{l} k \nabla \alpha_{v}$

where turbulent dispersion coefficient $C_{T D}=1.0$ was used.

Energy conservation equation. In a number of scenarios, it is reasonable to assume that the temperature of vapor inside bubbles is close to saturation. Ideally, the energy equation for the vapor should be solved. However, as a simplification, the vapor energy conservation equation is not solved, and the temperature of vapor mass is set to saturation. The source term due to wall heating goes entirely into the liquid phase:

$S_{l}=A_{w} \cdot q_{w}^{\prime \prime}$

According to the RPI model, the total heat flux from wall to liquid is partitioned into three components:

$q_{w}^{\prime \prime}=q_{l}^{\prime \prime}+q_{Q}^{\prime \prime}+q_{E}^{\prime \prime}$

which are liquid convective heat flux, quenching heat flux, and evaporative heat flux. Under sub-cooled boiling conditions, the wall surface is subdivided into portion $\Omega(0 \leq \Omega \leq 1)$, covered by nucleating bubbles, and portion $1-\Omega$, covered by fluid. Therefore, convective heat flux is expressed as: $q_{l}^{\prime \prime}=h_{l w} \cdot\left(T_{w}-T_{l}^{c e l l}\right) \cdot(1-\Omega)$

where $h_{l w}$, the single-phase heat transfer coefficient, is derived from either log law if flow is logarithmic or Fourier law if flow is laminar. Liquid phase properties must be used while calculating $h_{l w}$ for either turbulent or laminar flow.

Quenching heat flux $q_{Q}^{\prime \prime}$ models additional energy transfer related to liquid filling the wall vicinity after the bubble detachment:

$q_{Q}^{\prime \prime}=2 \pi^{-0.5} \Omega\left(f \kappa_{l} \rho_{l} C_{p l}\right)^{0.5}\left(T_{w}-T_{l}^{\text {cell }}\right)$

where $f$ is the bubble departure frequency, $\kappa$ is the thermal conductivity, $C$ is the specific heat, and $\rho$ is the density.

Evaporative heat flux is given by:

$q_{E}^{\prime \prime}=\frac{\pi}{6} d_{v w}^{3} f n \rho_{v} L$

where $d$ is the bubble departure diameter, $n$ is the nucleation site density, and $L$ is the latent heat.

In Eqs. 20-22, closure must be provided for wall boiling parameters. Correct prediction of bubble departure diameter $d_{v w}$ is very important because evaporation heat rate depends strongly on this parameter, according to Eq. 22. It can be calculated from the following relation (Unal [45], Wei and Morel [46]):

$d_{v w}=2.42 \cdot 10^{-5} \cdot p^{0.709} \cdot a \cdot(b \theta)^{-0.5}$

where all variables are in SI units. In Eq. 23:

$a=\frac{\left(T_{w}-T_{s}\right)}{2 \rho_{v}} \sqrt{\frac{\rho_{s} C_{p s} \kappa_{s}}{\pi}}$

$b=\frac{1}{2\left(1-\rho_{v} / \rho_{l}\right)} \operatorname{MAX}\left(\left(T_{s}-T_{l}\right), \frac{q_{w}^{\prime \prime}}{\left(0.0065 \rho_{l} C_{p l} U_{l}\right)}\right)$

$\theta=\operatorname{MAX}\left(U_{l} / 0.61,1.0\right)$

where subscript $s$ denotes the solid material of the wall where boiling occurs, $U$ is the free stream velocity, and $p$ is the pressure. In Eqs. 25 and 26, liquid temperature and velocity are local values at cells next to the wall. Because FLUENT 6.2 is an unstructured solver, the calculation of these parameters is impossible in the general case. Again, these correlations were originally developed for use in structured or one-dimensional codes. So instead of using local cross-section averaged values, local values at the cell next to the wall are used. This means that bubble departure diameter will be somewhat overestimated, but bubble departure diameter is not very sensitive to local sub-cooling, as follows from Eqs. 23 and 25. According to the experimental data of Prodanovic et al. [47], Eqs. 23-26 give reasonable agreement with experiments for water boiling at atmospheric pressure.

Nucleation site density is given by the following relation (Podowski [34]):

$n=\left(200\left(T_{w}-T_{\text {sat }}\right)\right)^{1.80}$

Bubble departure frequency is calculated as:

$f=\sqrt{\left(\frac{4 g\left(\rho_{l}-\rho_{v}\right.}{3 d_{v w} \rho_{l}}\right)}$

The effective wall area occupied by boiling sites is given by: 


$$
\Omega=\min \left(0.25 \cdot \pi d_{v w}^{2} n \eta, 1.0\right)
$$

where $\eta=4.8 \cdot \exp (-\mathrm{Ja} / 80)$, and Jacob number is given by (Kenning and Victor [48]) $J a=C_{p l} \cdot \rho_{l}\left(T_{s}-T_{l}\right) \cdot\left(\rho_{v} L\right)^{-1}$.

Bubble diameter in free stream is given by either a constant value or by Unal's correlation as a function of local subcooling $T_{\text {sub }}=T_{\text {sat }}-T_{l}$ (Kurul and Podowski [33]):

$$
d_{v}=\left(\begin{array}{l}
1.5 \cdot 10^{-4}, T_{\text {sub }}>13.5 \mathrm{~K} \\
1.5 \cdot 10^{-3}-10^{-4} \cdot T_{\text {sub }}, 0<T_{\text {sub }}<13.5 \mathrm{~K} \\
1.5 \cdot 10^{-3}, T_{\text {sub }}<0
\end{array}\right.
$$

Turbulence equations. The conventional mixture k-epsilon model contains two additional terms that describe additional bubble stirring and dissipation: one in turbulent kinetic energy and one in dissipation rate equation:

$$
\begin{aligned}
& S_{k}=0.75 \cdot C_{d} \cdot \rho_{l} \cdot \alpha_{v} \cdot\left|\vec{v}_{r}\right|^{2} / d_{v} \\
& S_{\varepsilon}=C_{\varepsilon 3} \frac{3 C_{d}\left|\vec{v}_{r}\right|}{d_{v}} S_{k}
\end{aligned}
$$

where $C_{\varepsilon 3}=0.45$ (Troshko and Hassan [49]).

It is important to validate models against experimental data. We believe not many validations-of CFD models with experimental data on boiling jets-have been reported in the literature. Therefore, the code is validated with two experimental studies on submerged boiling jets. The effect of aspects, such as jet orientation and nozzle diameter, is also explored numerically. These aspects are covered in the following sections.

Validation With Experimental Study of Katto and Kunihiro [11]. First, we examined the experimental study of Katto and Kunihiro [11]. The domain and the boundary conditions are shown in Fig. 3. A water jet with $3^{\circ} \mathrm{C}$ subcooling at atmospheric pressure (i.e., with $\mathrm{T}_{\text {inlet }}=97^{\circ} \mathrm{C}$ ) impinges on a 10 -mm-diameter disk with an inlet velocity of 2 $\mathrm{m} / \mathrm{s}$. The baseline nozzle diameter is $1.6 \mathrm{~mm}$, and the distance between the nozzle exit and the heated plate is maintained at 3 $\mathrm{mm}$. A heat flux is imposed on the hotplate surface, as shown in Fig. 3. This is a submerged jet configuration. An axisymmetric domain is established. The RNG k-epsilon model with standard wall functions is used. With the use of the standard wall function, the $y+$ close to the walls should be maintained above 11 .

All the results presented here are expected to be meshindependent to within 5\%. The properties of water at 1 atmosphere pressure are listed in Table 1. Figure 4 shows the comparison of the wall superheats from the experiments and CFD modeling.

There is ambiguity about the exact temperature measured in the experiments. All indications are that the stagnation point temperature is reported in the experiments. Figure 4 shows the stagnation as well as the average wall superheat. The experimental data are close to the stagnation superheat (within
$10 \%$ ), which is encouraging. Given the nature of this problem, uncertainties on the order of even $30 \%$ are acceptable. There is temporal fluctuation in all quantities-such as temperature, fluid volume fraction, mass flow rates, and energy transfer rates-obtained from the CFD simulations. A temporal average is reported here.

Figure 5 indicates the vapor volume fraction for two cases: heat flux of $50 \mathrm{~W} / \mathrm{cm}^{2}$ (left) and $100 \mathrm{~W} / \mathrm{cm}^{2}$ (right). For the $100 \mathrm{~W} / \mathrm{cm}^{2}$, the vapor volume fractions are much higher, as expected. Figure 6 lists the target surface superheat for two cases of $50 \mathrm{~W} / \mathrm{cm}^{2}$ (left) and $100 \mathrm{~W} / \mathrm{cm}^{2}$ (right). As expected, the superheat for the $100-\mathrm{W} / \mathrm{cm}^{2}$ case is higher than that for the $50-\mathrm{W} / \mathrm{cm}^{2}$ case. Also, the stagnation point is associated with the highest temperature, whereas away from the stagnation point, the temperature is almost uniform. Figure 7 shows the liquid temperature in the domain for the two cases of $50 \mathrm{~W} / \mathrm{cm}^{2}$ (left) and $100 \mathrm{~W} / \mathrm{cm}^{2}$ (right). The liquid temperature rises as it flows along the hotplate and reaches a maximum temperature almost at the edge of the plate. The stagnation point is not associated with any vapor formation and accumulation because the liquid is not heated up, and vapor condenses in the liquid. However, away from the stagnation point, as the liquid is heated up, the vapor

\begin{tabular}{|c|c|c|c|c|}
\hline & \multicolumn{2}{|l|}{ Water } & \multicolumn{2}{|l|}{ R-113 } \\
\hline & Liq. & Vap. & Liq. & Vap. \\
\hline $\begin{array}{l}\text { Saturation } \\
\text { temperatu- } \\
\text { re }\left({ }^{\circ} \mathrm{C}\right)\end{array}$ & 100 & & 47.6 & \\
\hline $\begin{array}{l}\text { Surface } \\
\text { tension } \\
(\mathbf{N} / \mathbf{m})\end{array}$ & 0.059 & & 0.014 & \\
\hline $\begin{array}{l}\text { Latent heat } \\
(\mathrm{J} / \mathrm{kg})\end{array}$ & $2,257,0$ & & 144,00 & \\
\hline $\begin{array}{l}\text { Density, } \\
\mathrm{kg} / \mathrm{m}^{3}\end{array}$ & 958 & 0.6 & 1,507 & 7.5 \\
\hline $\begin{array}{l}\text { Specific } \\
\text { heat, J/kg-K }\end{array}$ & 4,219 & 2,010 & 980 & 724 \\
\hline $\begin{array}{l}\text { Dynamic } \\
\text { viscosity, } \\
\mathrm{Ns}^{\prime} / \mathrm{m}^{2}\end{array}$ & $\begin{array}{l}2.83 \mathrm{e} \\
-04\end{array}$ & $\begin{array}{l}1.23 \mathrm{e} \\
-05\end{array}$ & $\begin{array}{l}5.23 \mathrm{e}- \\
04\end{array}$ & $\begin{array}{l}1.08 \mathrm{e} \\
-05\end{array}$ \\
\hline $\begin{array}{l}\text { Thermal } \\
\text { conductivity } \\
\text {, W/mK }\end{array}$ & 0.68 & 0.025 & 0.074 & 0.01 \\
\hline
\end{tabular}
formation is sustained. This is evident in Fig. 5.

Table 1. Properties of water and R-113 at 1 atmosphere pressure $(1.013 \mathrm{e}+05 \mathrm{~Pa})$ 


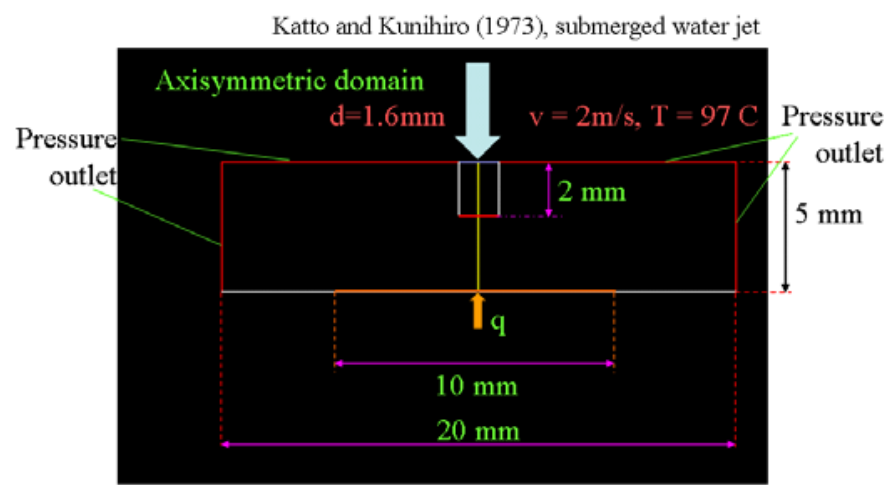

Fig. 3 Domain used for the Katto and Kunihiro [11] validation study

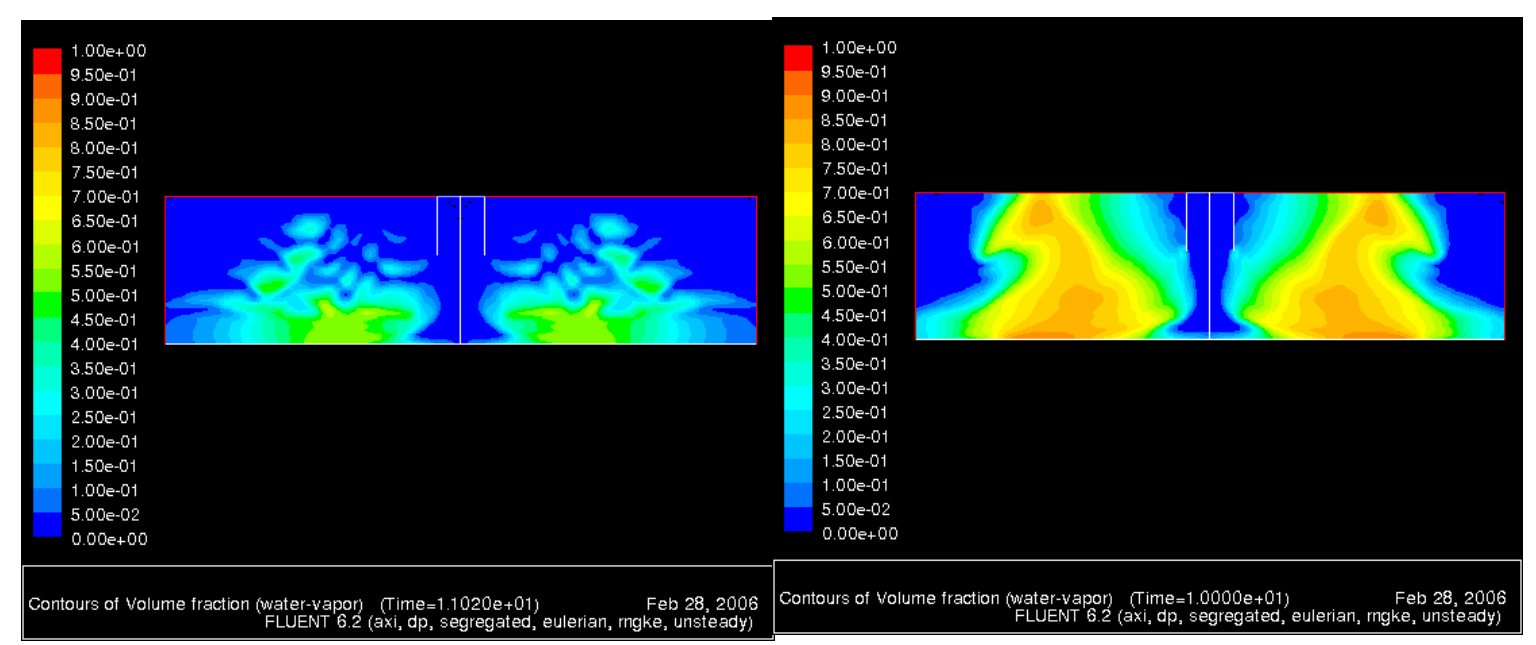

Fig. 5 Vapor volume fraction for two cases: $50 \mathrm{~W} / \mathrm{cm}^{2}$ (left) and $100 \mathrm{~W} / \mathrm{cm}^{2}$ (right)

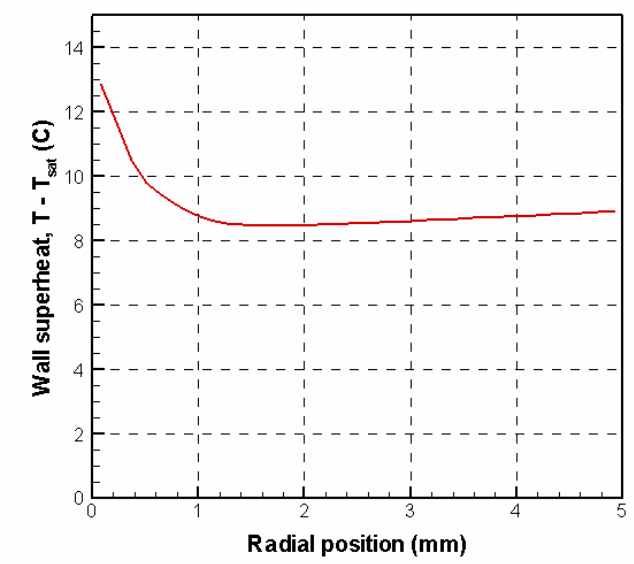

Fig. 6 Wall superheat for two cases: $50 \mathrm{~W} / \mathrm{cm}^{2}$ (left) and 100 $\mathrm{W} / \mathrm{cm}^{2}$ (right)

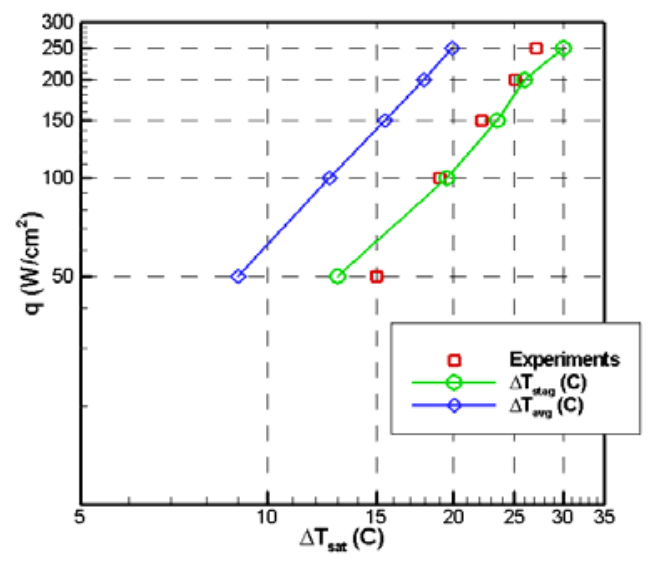

Fig. 4 Comparison of boiling curve from experiments (Katto and Kunihiro [11]) and CFD modeling 


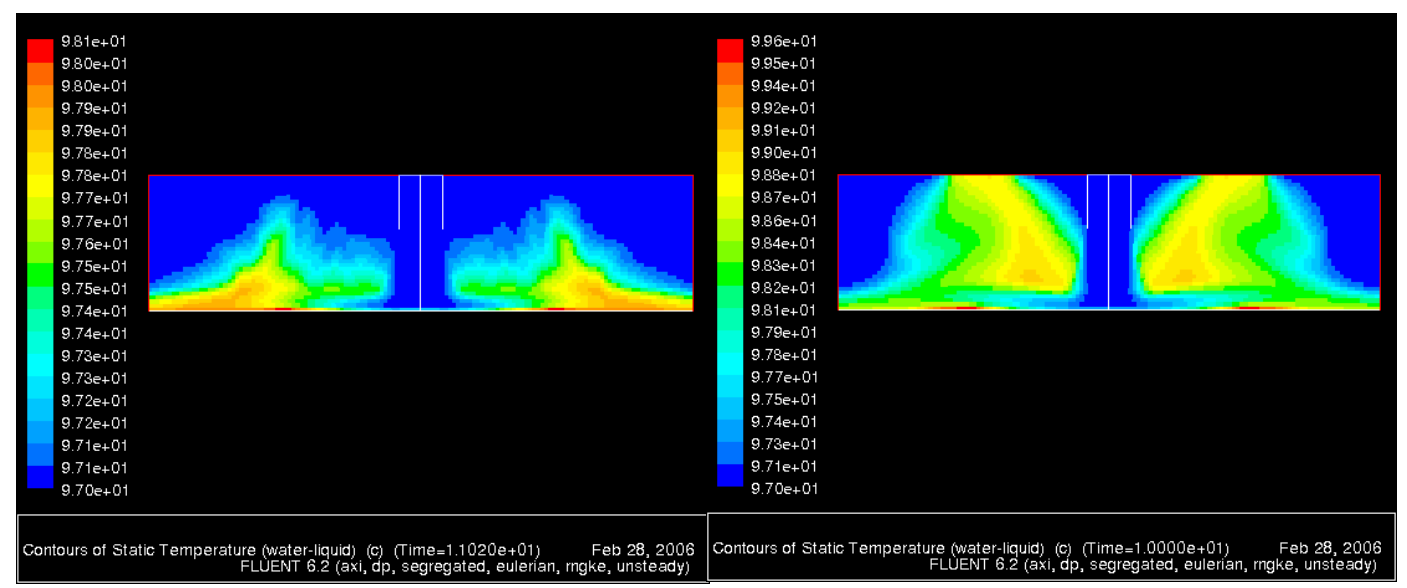

Fig. 7 Liquid temperature in the domain for two cases: 50 $\mathrm{W} / \mathrm{cm}^{2}$ (left) and $100 \mathrm{~W} / \mathrm{cm}^{2}$ (right)

Effect of jet orientation. Typically, experiments have revealed that jet orientation does not affect nucleate boiling $[5$, 13]. To study the effect of jet orientation with respect to gravity, in Fig. 3 [11] the direction of gravity was reversed. In one case, the direction of vapor rise is against gravity (the baseline case); in the other case, the direction of vapor rise is in line with gravity. The results are summarized in Table 2. For both cases (with $100 \mathrm{~W} / \mathrm{cm}^{2}$ ), there is not much difference in the average wall superheat and the stagnation superheat, which is in line with experimental observations. However, for the case in which the vapor rise is in line with gravity, the vapor volume fraction increases because gravity causes the vapor to get locked up near the walls. The small difference in liquid temperature may also be related to this effect.

Effect of nozzle diameter. The Katto and Kunihiro study [11] indicates that the jet diameter does not have much effect on the boiling curve. Here, the code is tested with this experimental observation. For the case of $100 \mathrm{~W} / \mathrm{cm}^{2}$, three nozzle diameters are used (Table 3). The 1.6- and 1.16-mm cases are comparable in terms of average wall superheat, liquid temperature, and vapor content. With the $1.6-\mathrm{mm}$ nozzle, the velocity is $2 \mathrm{~m} / \mathrm{s}$; with the $1.16-\mathrm{mm}$ nozzle, the velocity is $2.5 \mathrm{~m} / \mathrm{s}$; and with the $0.71-\mathrm{mm}$ nozzle, the velocity is $2.4 \mathrm{~m} / \mathrm{s}$. It is important to note that mass flow rate for three cases is not the same. The CFD results for the three cases (Table 3) match well with the experimental data (within 20\%).
Table 2. Effect of gravity on the thermal predictions for the case of $100 \mathrm{~W} / \mathrm{cm}^{2}$ (Katto and Kunihiro [11])

\begin{tabular}{|l|l|l|}
\hline & $\begin{array}{l}\text { Vapor rise } \\
\text { direction } \\
\text { against } \\
\text { gravity }\end{array}$ & $\begin{array}{l}\text { Vapor rise } \\
\text { direction in } \\
\text { line with } \\
\text { gravity }\end{array}$ \\
\hline $\begin{array}{l}\text { Average wall } \\
\text { superheat, K }\end{array}$ & 12.6 & 12.6 \\
\hline $\begin{array}{l}\text { Average liquid } \\
\text { temperature, K }\end{array}$ & 370.9 & 370.8 \\
\hline $\begin{array}{l}\text { Average vapor } \\
\text { content }\end{array}$ & 0.39 & 0.49 \\
\hline $\begin{array}{l}\text { Stagnation } \\
\text { superheat, K }\end{array}$ & 19 & 19 \\
\hline
\end{tabular}

Table 3. Effect of nozzle diameter on the thermal predictions for the case of $100 \mathrm{~W} / \mathrm{cm}^{2}$ (Katto and Kunihiro [11])

\begin{tabular}{|l|l|l|l|}
\hline Nozzle diameter & $\begin{array}{l}\mathbf{1 . 6} \\
\mathbf{m m}\end{array}$ & $\mathbf{1 . 1 6} \mathbf{~ m m}$ & $\begin{array}{l}\mathbf{0 . 7 1} \\
\mathbf{m m}\end{array}$ \\
\hline $\begin{array}{l}\text { Average wall } \\
\text { superheat, K }\end{array}$ & 12.6 & 12.6 & 13.86 \\
\hline
\end{tabular}


Impact of mesh refinement. The original mesh contained 2312 cells. The mesh was refined so that the total number of cells increased to 9248 . The average wall superheat was found to be $12.7 \mathrm{~K}$. For the original mesh, which had 2312 cells, the wall superheat was $12.6 \mathrm{~K}$. This suggests that the results from the original mesh are mesh-independent to well within $2 \%$.

\section{IGBT PACKAGE SIMULATIONS WITH BOILING JETS}

The previous section established some confidence in the CFD predictions of FLUENT by comparing them with experimental data from the literature. This section explores IGBT package simulations with boiling jets.

The axisymmetric domain used in the simulation is shown in Fig. 8. The IGBT package consists of several layers. The silicon die is mounted on a copper layer, followed by an aluminum nitride layer, another copper layer, and finally the aluminum baseplate/heat sink. Further details on the IGBT structure can be found in reference [50]. These boiling simulations are fairly intensive and take several hours to converge on 64-bit Linux machines with $1.4 \mathrm{GHz}$ processor speed-even with a small spatial mesh (i.e., small number of cells).

In the automotive industry, R134a is the working fluid used in the airconditioning units. Here we explore the possible use of $\mathrm{R} 134 \mathrm{a}$ as the cooling fluid for the IGBTs. The simulations presented here are performed with an R134a (properties given in Table 4) jet inlet temperature of $47^{\circ} \mathrm{C}$. For the boiling simulations, the pressure is maintained at $1.318 \mathrm{e}+06 \mathrm{~Pa}$ (i.e. 13 atmospheres), at which the saturation temperature of the $\mathrm{R} 134 \mathrm{a}$ is $50^{\circ} \mathrm{C}$. So there is a $3^{\circ} \mathrm{C}$ sub-cooling in the $\mathrm{R} 134 \mathrm{a}$ temperature at the inlet. A volumetric heat generation term is included in the silicon layer to simulate heat dissipate. The heat dissipation in the silicon die is $25 \mathrm{~W} / \mathrm{cm}^{2}$. This corresponds to a heat dissipation of $20.3 \mathrm{~W}$. The jet inlet velocity is $2 \mathrm{~m} / \mathrm{s}$ (Fig. 9). Figures 9 and 10 show the velocity and temperature contours, respectively, in the domain. A maximum temperature of $56^{\circ} \mathrm{C}$ is attained. The maximum temperatures are in the silicon die, as expected. The domain used for this simulation contains 5506 cells. A simulation was performed with 22024 cells also. The results for the maximum temperature in the domain within this refined mesh were within $2 \%$ of the results from the original baseline mesh The vapor volume fraction in the domain is shown in Fig. 11. The volume-averaged vapor fraction for this case is $17 \%$ (Table 5). Figure 11 also gives a hint that in this reduced IGBT structure, the vapor does not have a very clear removal path. It tends to get trapped to some extent because of the confining copper and aluminum walls.

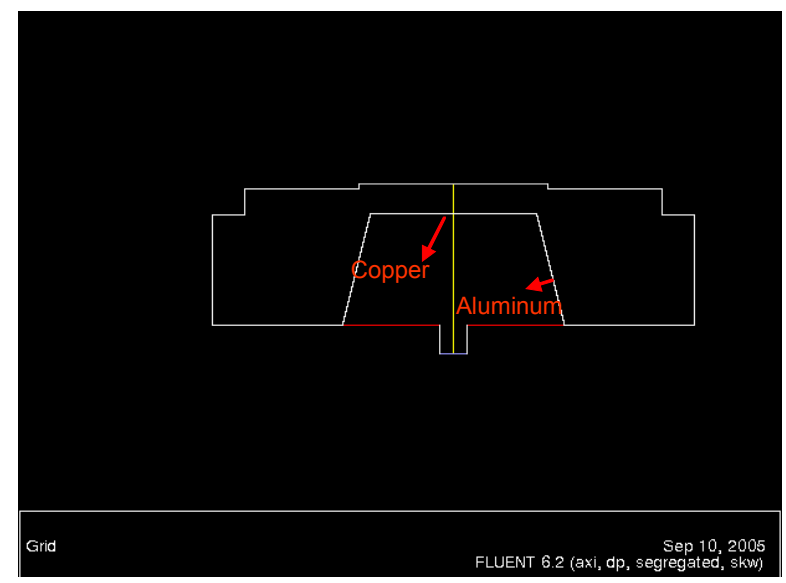

Fig. 8 Axisymmetric domain used for the IGBT package simulation

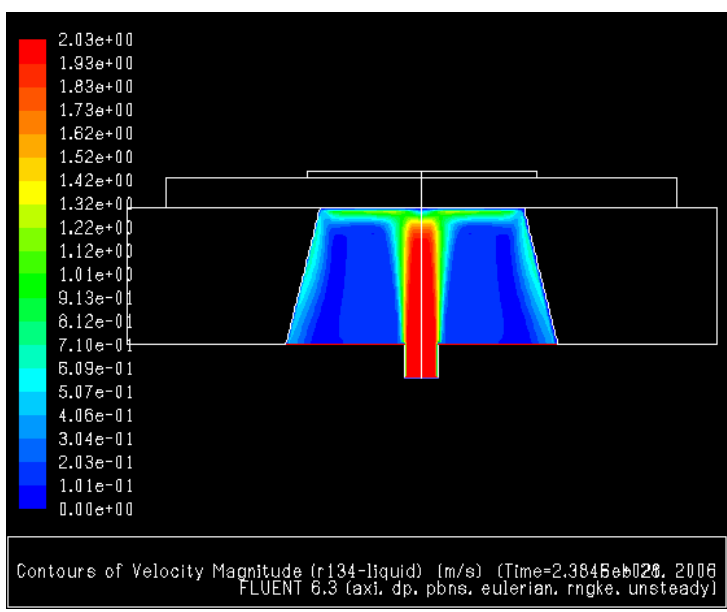

Fig. 9 Velocity contours in the domain

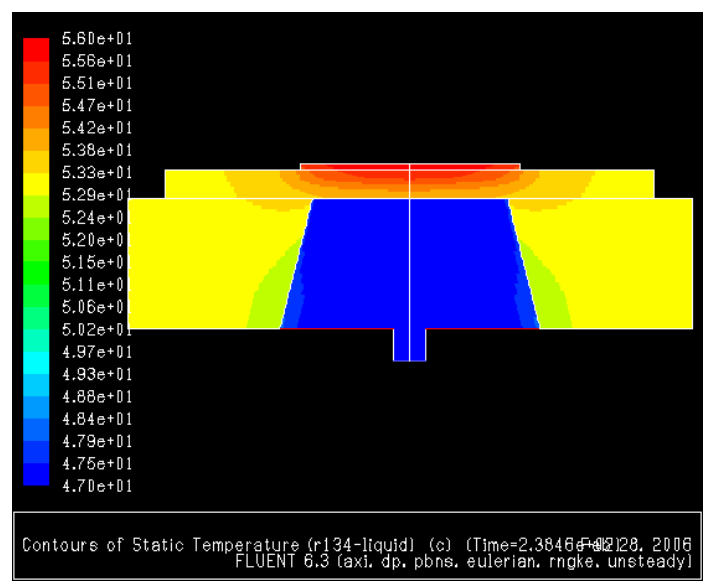

Fig. 10 Temperature contours in the domain $-25 \mathrm{~W} / \mathrm{cm}^{2}$ 


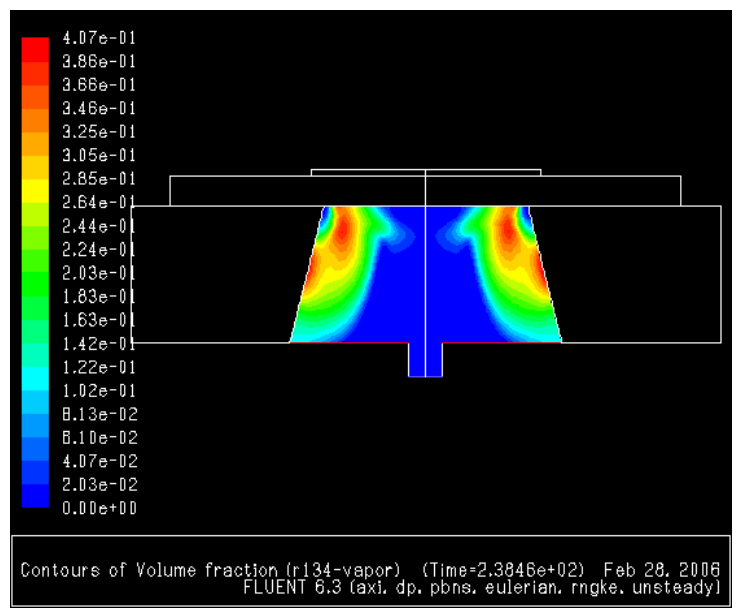

Fig. 11 Contours of vapor volume fraction $-25 \mathrm{~W} / \mathrm{cm}^{2}$

It would be illustrative to compare the performance of singlephase and boiling jets in the context of the IGBT package cooling. Figure 12 shows such a comparison for the case of 25 $\mathrm{W} / \mathrm{cm}^{2}$. The plot on the left in Fig. 12 is the same as the plot in Fig. 10, whereas the plot on the right in Fig. 12 is the case in which there is no boiling, and everything else is identical to the case mentioned in this section. Table 5 also has a summary of all the results with and without boiling. For the cases not involving any boiling, the bubble nucleation site density is equal to zero. In all other aspects, they are similar to the case involving boiling. This facilitates a direct comparison between the results of the two cases. The maximum temperature in the domain (silicon die) is $69.8^{\circ} \mathrm{C}$. The case involving boiling therefore gives maximum temperatures almost $13.8^{\circ} \mathrm{C}$ lower than the case not involving any boiling (Table 5). This is a significant difference. These results hint at the advantage that heat of the fluid, boiling may be yielding lower die temperatures than comparable single-phase flows.

Of course, these numerical results need to be validated experimentally. The validations presented in Section 2 give some degree of confidence in the predictions from the code. It would be interesting to see how experimental results from the IGBT package involving boiling would match up with the predictions presented here. Overall, there is evidence of the benefits of boiling from a heat transfer standpoint. It is important to note that this model is applicable only in the bubbly flow regime. This implies that the liquid should be the dominant phase and the vapor bubbles should be the secondary phase. If there is intense boiling with a large amount of vapor formation, the basic model may not be applicable. Such regimes remain an area of research. Although experiments are essential, modeling can yield very useful information when used within their range of applicability. Tools such as those presented in the paper can be explored for thermal design involving the use of R134a or any other fluid for thermal management in power electronics as well as other applications.

\section{Summary \& Conclusions}

The CFD model and code are validated against experimental studies involving submerged jets. To the best of our knowledge, this is the first time such validations are being reported. A reasonable match is found between the experimental boiling curves and those obtained by CFD. IGBT package simulations suggest that, for the case examined here, boiling jets are providing significant benefits over non-boiling jets. A tool has been established that can be used for thermal design of two-phase cooling systems in the power electronics context.

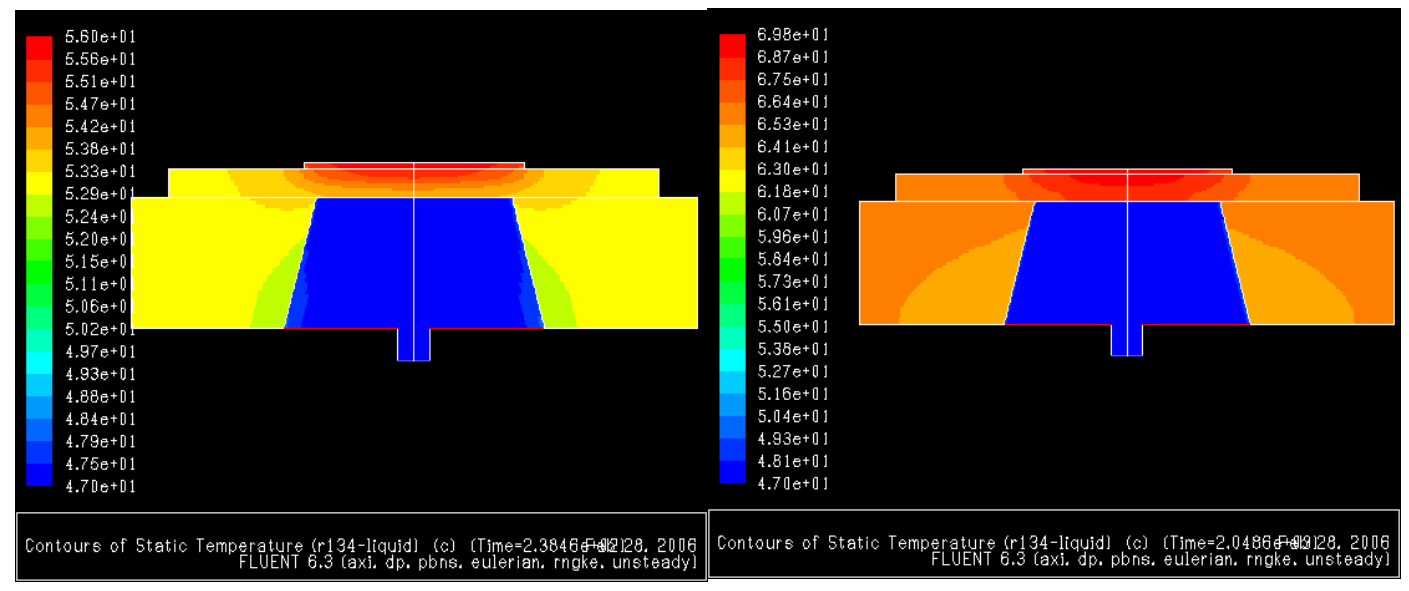

Fig. 12: Temperature contours in the domain with boiling (left) and without boiling (right) $-25 \mathrm{~W} / \mathrm{cm}^{2}$ 
Table 4. Properties of R134a at $1.318 \mathrm{e}+06 \mathrm{~Pa}$, saturation temperature $=323.15 \mathrm{~K}$

\begin{tabular}{|c|c|c|}
\hline & Liquid & Vapor \\
\hline Density, $\mathrm{kg} / \mathrm{m}^{3}$ & 1103.4 & 66.16 \\
\hline Specific heat, J/kgK & 1575 & 1219 \\
\hline $\begin{array}{c}\text { Thermal } \\
\text { conductivity, W/mK }\end{array}$ & 0.0735 & 0.018 \\
\hline $\begin{array}{c}\text { Dynamic viscosity, } \\
\mathrm{kg} / \mathrm{ms}\end{array}$ & 0.000167 & 0.0000138 \\
\hline
\end{tabular}

Table 5. Summary of results obtained from IGBT package simulations

\begin{tabular}{|l|l|l|}
\hline \multirow{2}{*}{} & $25 \mathrm{~W} / \mathrm{cm}^{2}$ \\
\cline { 2 - 3 } & $\begin{array}{l}\text { With } \\
\text { boiling }\end{array}$ & $\begin{array}{l}\text { Without } \\
\text { boiling }\end{array}$ \\
\hline $\mathrm{T}_{\max }\left({ }^{\circ} \mathrm{C}\right)$ & 56 & 69.8 \\
\hline $\begin{array}{l}\text { Volume averaged vapor } \\
\text { fraction }\end{array}$ & 0.17 & 0 \\
\hline $\begin{array}{l}\text { Volume averaged liquid } \\
\text { temperature }\left({ }^{\circ} \mathrm{C}\right)\end{array}$ & 47.3 & 47.3 \\
\hline
\end{tabular}

\section{Acknowledgments}

We acknowledge the support and funding provided by Susan Rogers, the program manager for the advanced power electronics and electric machines project under the U.S. Department of Energy FreedomCAR Program.

\section{References}

[1] Webb, B.W. and Ma, C.-F., 1995, "Single-phase liquid jet impingement heat transfer", Advances in Heat Transfer, 26, pp. 105-217.

[2] Lienhard, J.H., 1995, "Liquid jet impingement", in Annual Review of Heat Transfer, pp. 199-270.

[3] Garimella, S.V., 2000, "Heat Transfer and flow fields in confined jet impingement", in Annual Review of Heat Transfer, pp. 413-494.

[4] Narumanchi, S.V.J., Amon, C.H., and Murthy, J.Y., 2003, "Influence of pulsating submerged liquid jets on chip-level thermal phenomena", ASME Journal of Electronic Packaging, 125, pp. 354-361.

[5] Wolf, D.H., Incropera, F.P., and Viskanta, R., 1993, "Jet impingement boiling", Advances in Heat Transfer, 23, pp. 1132.

[6] Zhou, D.W. and Ma, C.F., 2004, "Local jet impingement boiling heat transfer with R113", Heat and Mass Transfer, 40, pp. 539-549.

[7] Mudawar, I., 2000, "Assessment of high-heat-flux thermal management schemes", in International conference on thermal, mechanics and thermomechanical phenomena in electronic systems, Las Vegas, NV, ASME, pp. 1-20.
[8] Mitsutake, Y. and Monde, M., 2003, "Ultra high critical heat flux during forced flow boiling heat transfer with an impinging jet", ASME Journal of Heat Transfer, 125, pp. 1038-1045.

[9] Liu, Z.-H., Tong, T.-F., and Qiu, Y.-H., 2004, "Critical heat flux of steady boiling for subcooled water jet impingement on the flat stagnation zone", ASME Journal of Heat Transfer, 126, pp. 179-183.

[10] Copeland, R.J., 1970, "Boiling heat transfer to a water jet impinging on a flat surface (-1g)",Ph.D. thesis, Department of Mechanical Engineering, Southern Methodist University, Dallas, TX.

[11] Katto, Y. and Kunihiro, M., 1973, "Study of the mechanism of burn-out in boiling system of high burn-out heat flux", Bull. JSME, 16(99), pp. 1357-1366.

[12] Katto, Y. and Monde, M., 1974, "Study of mechanism of burn-out in a high heat-flux boiling system with an impinging jet", in 5th International Heat Transfer Conference, B6.2, pp. 245-249.

[13] Monde, M. and Katto, Y., 1978, "Burnout in a high heatflux boiling system with an impinging jet", Int. J. Heat Mass Transfer, 21, pp. 295-305.

[14] Monde, M., 1980, "Burnout heat flux in saturated forced convection boiling with an impinging jet", Heat Transfer Japanese Research, 9(1), pp. 31-41.

[15] Ma, C.-F. and Bergles, A.E., 1983, "Boiling jet impingement cooling of simulated microelectronic chips", in Heat Transfer in Electronic Equipment, ASME, New York, HTD-Vol. 28, pp. 5-12.

[16] Ma, C.-F. and Bergles, A.E., 1986, "Jet impingement nucleate boiling", Int. J. Heat Mass Transfer, 29(8), pp. 10951101.

[17] Ruch, M.A. and Holman, J.P., 1975, "Boiling heat transfer to a Freon-113 jet impinging upward onto a flat, heated surface", Int. J. Heat Mass Transfer, 18, pp. 51-60.

[18] Katto, Y. and Ishii, K., 1978, "Burnout in a high heat flux boiling system with a forced supply of liquid through a plane jet", in Proceedings of the 6th International Heat Transfer Conference, 1, FB-28, pp. 435-440.

[19] Miyasaka, Y., Inada, S., and Owase, Y., 1980, "Critical heat flux and subcooled nucleate boiling in transient region between a two-dimensional water jet and a heated surface", J. Chem. Eng. Jpn., 13, pp. 29-35.

[20] Mudawar, I. and Wadsworth, D.C., 1991, "Critical heat flux from a simulated chip to a confined rectangular impinging jet of dielectric liquid", Int. J. Heat Mass Transfer, 34(6), pp. 1465-1479.

[21] Wadsworth, D.C. and Mudawar, I., 1990, "Cooling of a multichip electronic module by means of confined twodimensional jets of dielectric liquid", ASME Journal of Heat Transfer, 112, pp. 891-898.

[22] Nonn, T., Dagan, Z., and Jiji, L.M., 1988, "Boiling jet impingement cooling of simulated microelectronic heat sources", in Winter Annual Meeting, Chicago, Illinois, ASME, 88-WA/EEP-3, pp. 1-9.

[23] Nonn, T., Dagan, Z., and Jiji, L.M., 1989, "Jet impingement flow boiling of a mixture of FC-72 and FC-87 liquids on a simulated electronic chip", in National Heat Transfer Conference, HTD-Vol. 111, pp. 121-128. 
[24] Monde, M., Kusuda, H., and Uehara, H., 1982, "Burnout heat flux in saturated forced convection boiling with two or more impinging jets", Heat Transfer - Japanese Research, pp. 18-31.

[25] Monde, M. and Mitsutake, Y., 1996, "Critical heat flux in forced convective subcooled boiling with multiple impinging jets", ASME Journal of Heat Transfer, 117, pp. 241-243.

[26] Pais, M.R., Chow, L.C., and Mahefkey, E.T., 1993, "Multiple jet impingement cooling", Journal of Thermophysics and Heat Transfer, 7(3), pp. 435-440.

[27] Rohsenow, W.M., 1952, "A method of correlating heattransfer data for surface boiling of liquids", Trans. Am. Soc. Mech. Engrs., Paper No. 51-A110, 74, pp. 969-976.

[28] Sharan, A. and Lienhard, J.H., 1985, "On predicting burnout in the jet-disk configuration", ASME Journal of Heat Transfer, 107, pp. 398-401.

[29] Katto, Y. and Yokoya, S., 1988, "Critical heat flux on a disk heater cooled by a circular jet of saturated liquid impinging at the center", Int. J. Heat Mass Transfer, 31(2), pp. 219-227.

[30] Monde, M., 1985, "Critical heat flux in saturated forced convective boiling on a heated disk with an impinging jet", Warme-und Stoffubertragung, 19, pp. 205-209.

[31] Monde, M., 1987, "Critical heat flux in saturated forced convection boiling on a heated disk with an impinging jet", ASME Journal of Heat Transfer, 109, pp. 991-996.

[32] Monde, M. and Inoue, T., 1991, "Critical heat flux in saturated forced convective boiling on a heated disk with multiple impinging jets", ASME Journal of Heat Transfer, 113, pp. 722-727.

[33] Kurul, N. and Podowski, M.Z., 1990, "Multidimensional effects in forced convection subcooled boiling", in Ninth International Heat Transfer Conference, Jerusalem, Israel, 1BO-04, pp. 21-26.

[34] Podowski, R.M., et al., 1997, "A mechanistic model of the ebullition cycle in forced convection subcooled boiling", in Eighth International Topical Meeting on Nuclear Reactor Thermal-Hydraulics, Kyoto, Japan, 3, pp. 1535-1542.

[35] Wang, D., Yu, E., and Przekwas, A., 1999, "A computational study of two phase jet impingement cooling of an electronic chip", in Fifteenth IEEE Semi-therm Symposium, IEEE, pp. 10-15.

[36] Seiler, N., et al., 2003, "Modeling and computation of heat exchanges in the configuration of an impinging jet on a hot plate", in International conference on supercomputing in nuclear applications, SNA 2003, Paris, France, pp. 1-13.

[37] Mukherjee, A. and Dhir, V.K., 2004, "Study of lateral merger of vapor bubbles during nucleate pool boiling", ASME Journal of Heat Transfer, 126, pp. 1023-1039.

[38] Agarwal, D.K., et al., 2004, "Planar simulation of bubble growth in film boiling in near-critical water using a variant of the VOF method", ASME Journal of Heat Transfer, 126, pp. 329-338.

[39] Esmaeeli, A. and Tryggvason, G., 2004, "Computations of film boiling. Part I: numerical method", International Journal of Heat and Mass Transfer, 47, pp. 5451-5461.

[40] Esmaeeli, A. and Tryggvason, G., 2004, "Computations of film boiling. Part II: multi-mode film boiling", International Journal of Heat and Mass Transfer, 47, pp. 5463-5476.
[41] Estes, K.A. and Mudawar, I., 1995, "Comparison of twophase electronic cooling using free jets and sprays", ASME Journal of Electronic Packaging, 117, pp. 323-332.

[42] Lin, L. and Ponnappan, R., 2003, "Heat transfer characteristics of spray cooling in a closed loop", International Journal of Heat and Mass Transfer, 46, pp. 3737-3746.

[43] Pautsch, A.G. and Shedd, T.A., 2005, "Spray impingement cooling with single- and multiple-nozzle arrays. Part I. Heat transfer data using FC-72", International Journal of Heat and Mass Transfer, 48, pp. 3167-3175.

[44] Moraga, F.J., Bonetto, F.J., and Lahey, R.T., 1999, "Lateral forces on spheres in turbulent uniform shear flow", International Journal of Multiphase Flow, 25, pp. 1321-1372.

[45] Unal, H.C., 1976, "Maximum bubble diameter, maximum bubble-growth time and bubble-growth rate during the subcooled nucleate flow boiling of water up to $17.7 \mathrm{MN} / \mathrm{m}^{2 "}$, Int. J. Heat Mass Transfer, 19, pp. 643-649.

[46] Wei, Y. and Morel, C., 2002, "Prediction of parameters distribution of upward boiling two-phase flow with two-fluid model", in Proceedings of ICONE 10, Arlington, VA, USA, 10, pp.

[47] Prodanovic, V.A., 2002, "Bubble behavior in subcooled flow boiling of water at low pressures and low flow rates", Int. J. Multiphase Flow, 28(1), pp. 1-19.

[48] Kenning, D.B.R. and Victor, H.T., 1981, "Fullydeveloped nucleate boiling: overlap of areas of influence and interference between bubble sites", Int. J. Heat Mass Transfer, 24(6), pp. 1025-1032.

[49] Troshko, A.A. and Hassan, Y.A., 2001, "A two-equation turbulence model of turbulent bubbly flows", International Journal of Multiphase Flow, 27, pp. 1965-2000.

[50] Narumanchi, S.V.J., Hassani, V., and Bharathan, D., 2005, "Modeling single phase and boiling liquid jet impingement cooling in power electronics", National Renewable Energy Laboratory, NREL/TP-54038787,http://www.nrel.gov/docs/fy06osti/38787.pdf. 


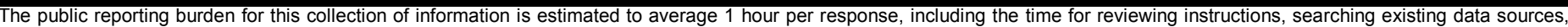

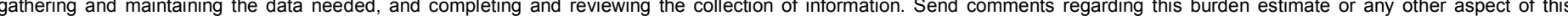

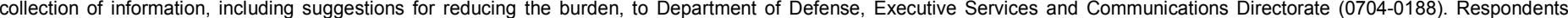

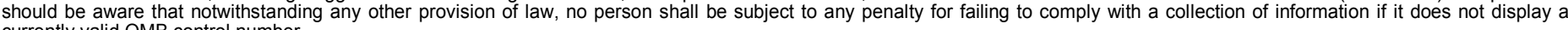
currently valid OMB control number.

PLEASE DO NOT RETURN YOUR FORM TO THE ABOVE ORGANIZATION.

\section{REPORT DATE (DD-MM-YYYY) \\ December 2006 \\ 2. REPORT TYPE \\ Conference paper}

4. TITLE AND SUBTITLE

Numerical Simulations of Boiling Jet Impingement Cooling in Power Electronics
3. DATES COVERED (From - To)

5a. CONTRACT NUMBER

DE-AC36-99-G010337 5b. GRANT NUMBER

5c. PROGRAM ELEMENT NUMBER

5d. PROJECT NUMBER

NREL/CP-540-39401

5e. TASK NUMBER

FC06.7010

5f. WORK UNIT NUMBER
7. PERFORMING ORGANIZATION NAME(S) AND ADDRESS(ES)

National Renewable Energy Laboratory

1617 Cole Blvd.

Golden, CO 80401-3393
8. PERFORMING ORGANIZATION REPORT NUMBER

NREL/CP-540-39401

9. SPONSORING/MONITORING AGENCY NAME(S) AND ADDRESS(ES)

10. SPONSOR/MONITOR'S ACRONYM(S) NREL

11. SPONSORING/MONITORING AGENCY REPORT NUMBER

\section{DISTRIBUTION AVAILABILITY STATEMENT}

National Technical Information Service

U.S. Department of Commerce

5285 Port Royal Road

Springfield, VA 22161

\section{SUPPLEMENTARY NOTES}

\section{ABSTRACT (Maximum 200 Words)}

This paper explores turbulent boiling jet impingement for cooling power electronic components in hybrid electric vehicles.

\section{SUBJECT TERMS}

boiling jet impingement; power electronics; numerical simulations; CFD; IGBTs; power electronic cooling applications; hybrid electric vehicles

\begin{tabular}{|c|c|c|c|}
\hline \multicolumn{3}{|c|}{ 16. SECURITY CLASSIFICATION OF: } & \multirow{2}{*}{$\begin{array}{l}\text { 17. LIMITATION } \\
\text { OF ABSTRACT } \\
\text { UL }\end{array}$} \\
\hline $\begin{array}{l}\text { a. REPORT } \\
\text { Unclassified }\end{array}$ & $\begin{array}{l}\text { b. ABSTRACT } \\
\text { Unclassified }\end{array}$ & $\begin{array}{l}\text { c. THIS PAGE } \\
\text { Unclassified }\end{array}$ & \\
\hline
\end{tabular}

18. NUMBER
OF PAGES

19a. NAME OF RESPONSIBLE PERSON

19b. TELEPONE NUMBER (Include area code) 